\title{
Correction to: Corporate social responsibility and governance
}

\author{
Jean-Michel Sahut ${ }^{1} \cdot$ Marta Peris-Ortiz $^{2} \cdot$ Frédéric Teulon $^{3}$
}

Published online: 28 September 2019

(c) Springer Science+Business Media, LLC, part of Springer Nature 2019

\section{Correction to: Journal of Management and Governance https://doi.org/10.1007/s10997-019-09472-2}

The original version of this article contained a mistake. The list of the authors was incorrect. The authors of this article are: Jean-Michel Sahut, Marta Peris-Ortiz, Frédéric Teulon.

The original article has been corrected.

Publisher's Note Springer Nature remains neutral with regard to jurisdictional claims in published maps and institutional affiliations.

The original article can be found online at https://doi.org/10.1007/s10997-019-09472-2.

Jean-Michel Sahut

jmsahut@gmail.com

1 IDRAC Business School, Lyon, France

2 Universitat Politècnica de València, Valencia, Spain

3 IPAG Business School, Paris, France 